\title{
Konsep al-Akhlak al-Karimah: Studi Komparasi Pemikiran Syekh Abd al-Wahhab al-Sya'rani dalam Kitab al-Minan al-Kubra dengan Syekh Muhammad Abd al-Aziz al-Khawli dalam Kitab al-Adab al-Nabawi
}

\author{
Ikhfanudin \\ Jurusan Tasawuf dan Psikoterapi \\ Fakultas Ushuluddin UIN Sunan Gunung Djati Bandung, Indonesia \\ ikhfanudin307@gmail.com
}

\begin{abstract}
Morals are the implementation of one's faith when meeting other people, other creatures or even meeting their Lord. So the discussion will not run out of time. Then in modern times, people begin to appear who heresy someone else just because they think that person does not practice morals in accordance with the guidance of the Prophet. The accusation is often leveled at the Sufis, especially the Sufis who often 'uzlah and do things outside the habits of other humans. Even though this is not true, the true Sufis are people who do worship both socially and individually in a way that is based on the Prophet Muhammad Saw and they will do it with sincerity. So we aim to combine the thoughts of a hadith expert with a Sufism expert to see how true the irregularities they throw at the Sufis are. This study uses a literature review method or literature study with analytical techniques comparing the opinions of two figures related to noble character. This study aims to find common ground between the opinions of Sheikh Abdul Wahhab al-Sya'rani and Sheikh Muhammad Abdul Aziz alKhawli regarding morality.
\end{abstract}

Keywords: Guidance of the Prophet, Moral, Sufism.

\begin{abstract}
Abstrak
Akhlak merupakan implementasi iman seseorang saat bertemu dengan orang lain, makhluk lain atau bahkan bertemu dengan Tuhannya. Maka pembahasannya tidak akan habis termakan masa. Kemudian di masa-masa kini, mulailah muncul orang yang membid'ahkan seseorang lain hanya karena menganggap orang tersebut tidak menjalankan akhlak sesuai dengan tuntunan Nabi. Tuduhan itu sering kali terlontarkan kepada kaum sufi, terutama kaum sufi yang sering 'uzlah dan melakukan hal di luar kebiasaan manusia lainnya. Padahal, hal itu tidaklah benar, sufi yang benar
\end{abstract}


adalah orang yang melakukan ibadah baik sosial maupun individual dengan jalan yang disandarkan kepada Nabi Muhammad Saw dan mereka akan melakukan hal tersebut dengan keikhlasan. Maka kami bertujuan untuk memadukan pemikiran seorang ahli hadits dengan ahli tasawuf untuk melihat seberapa benar kejanggalan yang mereka lontarkan kepada kaum sufi. Penelitian ini menggunakan metode literature review atau studi putaka dengan teknik analisis membandingkan pendapat dua orang tokoh terkait akhlak mulia. Penelitian ini bertujuan agar ditemukannya titik temu antara pendapat Syekh Abdul Wahhab al-Sya'rani dan Syekh Muhammad Abdul Aziz al-Khawli mengenai akhlak.

Kata kunci: Akhlak, Sufi, Tuntunan Nabi.

\section{Pendahuluan}

Berbicara tentang akhlak tidak akan pernah menemui titik akhir, karena akhlak selalu menjadi tolak ukur iman seseorang di hadapan orang lain. Jika iman merupakan dapur seseorang, maka akhlak adalah ruang tamunya. Tamu hanya dapat menilai rumah tersebut dengan hal yang ada di ruang tamunya, bukan yang ada di dapurnya. Begitu juga manusia. Penilaian akan dihadapkan kepada akhlaknya, karena itulah yang nampak oleh orang lain. Karena pentingnya akhlak bahkan visi utama Nabi yang pernah beliau utarakan dalam sabdanya adalah penyempurnaan akhlak. "Sesungguhnya aku diutus untuk menyempurnakan akhlak yang mulya" (HR. Ahmad).

Tasawuf sebagai salah satu fan ilmu juga pada hakikatnya mempelajari bagaimana seseorang bisa memiliki akhlak yang baik. Ditunjukan dengan tahapan yang ada dalam ajaran tasawuf, dengan dimulai dari menghilangkan segala macam hal buruk dalam diri (takhalli) kemudian dilanjutkan dengan menaburi akhlak-akhlak mulia sebagai hiasan diri seseorang (tahalli) yang kemudian akan berlanjut pada tahap seseorang akan terus-menerus berkonsisten untuk berdzikir seraya beramal shalih dengan sendirinya seakan Tuhan menggerakkan perilakunya (tajalli) (Hasan, 2014).

Tetapi praktik sufi (pengamal ajaran tasawuf) sering dianggap sebagai bid'ah atau hal yang tidak sesuai dengan syari'at. Terutama ketika kaum sufi menyanjung Tuhan mereka dengan cara yang tidak lazim dilakukan khalayak umum seperti menari dan lain sebagainya (Abdillah, 2012). Mendengar akan anggapan ini, orang-orang yang awam pasti kemudian terdoktrin dan memilih untuk enggan mempelajari tasawuf, karena takut terjerumus dalam jurang bid'ah dan kesesatan. Dan ternyata 
ketakutan tersebut tidak hanya ada pada orang yang awam ilmu pengetahuan, tetapi beberapa ulama juga menakutan hal tersebut. Sampaisampai mengklaim bahwa kekacauan spiritual akan terjadi jika kaum sufi diakui dengan jalan kebatinannya tersebut, karena pada dasarnya kebatinan bukanlah wilayah yang sanggup manusia arungi (Rahman, 2017). Karena banyaknya pro-kontra beberapa masyarakat sampai tidak mengenal sama sekali apa itu tasawuf. Jangankan untuk mengenal, mendengar namanya saja tidak.

Akhlak didefinisikan oleh al-Ghazali sebagai keadaan jiwa yang menjadi sumber semua perliaku tanpa adanya pemikiran dan penelitian untuk melakukannya. Selain itu akhlak yang berasal dari bahasa Arab yaitu al-khalqu (kejadian) dan al-khuluqu (tingkah laku) yang keduanya merupakan hal yang berlawanan yaitu dlahir dan batin. Beliau berpendapat bahwa asal kata dari akhlak ini berhubungan dengan manusia yang tersusun dari bentuk jasad (dlahir) yang dapat terlihat oleh mata pada normalnya serta bentuk jiwa atau ruh (batin) yang hanya bisa terlihat oleh hati. Dari kedua unsur ini hal yang lebih dominan memiliki nilai lebih besar merupakan ruh atau jiwa dari pada jasad yang justru tak terlihat oleh kasat mata. Hal ini berlandaskan firman Allah Swt pada surat Shad ayat 71-72 (Lubis, 2012):

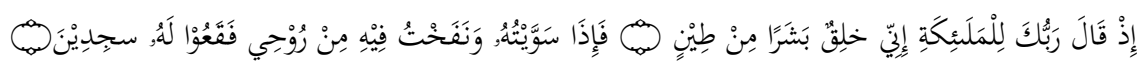

“(Ingatlah) Ketika Tuhanmu berkata pada pada malaikat: Sesungguhnya Aku menciptakan manusia dari tanah dan ketika telah Kusempurnakan dan telah Kutitipkan ke dalamnya ruh-Ku, hendaklah kamu tunduk merendahkan diri kepada-Nya."

Imam al-Ghazali dalam karya agungnya yaitu Ihya Ulum al-Din mengatakan bahwa husnul khuluq atau biasa disebut juga sebagai akhlak yang mulia (akhlak karimah) merupakan sifat dari Rasulullah Saw dan perilaku para Shiddiqin. Akhlak merupakan bagian dari agama yang membutuhkan usaha yang keras dan kesungguhan untuk mendapatkannya, karena akhlak mulia merupakan buah dari kesungguhan orang bertakwa dan riyadlah para hamba yang senantiasa menyembah Tuhannya (Al-Ghazali, 2020).

Banyak lagi ulama lain yang mengutarakan pendapatnya tentang definisi akhlak yang mulia. Di antaranya adalah Hamka yang merupakan ulama modern dari Sumatera juga mengutarakan definisi akhlak al-karimah yang sama dengan al-Ghazali. Hamka mendefinisikan bahwa budi pekerti yang luhur merupakan perangai dari para Rasul, orang-orang terhormat, 
sifat orang-orang muttaqin (orang yang bertakwa) dan hasil dari perjuangan seorang hamba (abid) (Hamka, 2017).

Terdapat beberapa penelitian terdahulu yang berkaitan dengan penelitian dalam artikel ini. Di antarnya terdapat dalam buku Abdul Wahab Asy-Sya'ra ñi: Sufisme dan Perkembangan Pendidikan Karakter. Buku ini dikarang oleh $\mathrm{H}$. Zubaidi untuk megupas tuntas pendidikan akhlak berbasis sufistik dengan mengacu pada Syekh al-Sya'rani. Dimulai dari adanya kehampaan spiritual masyarakat yang saat ini sudah menjadi hal yang sangat normal terjadi, karena pengedepanan masyarakat terhadap perkembangan ilmu pengetahuan dan melupakan dimensi spiritualnya. Bahkan di tingkat pendidikan apapun selalu mengedepankan nilai akademik untuk bisa menaikkan level dari peserta didiknya, padahal pendidikan bukan hanya tentang nilai akademik, akan tetapi juga tentang adab dan tingkah laku dari siswanya. Tidak hanya dalam lingkup umum, pendidikan yang berbasis Islami yang diharapkan bisa menjadi salah satu solusi dari sekian masalah pendidikan yang ada juga menjadi masalah baru ketika pendidikan ini dianggap sebagai himpunan pembelajaran fikih. Pendidikan yang mengedepankan cara seseorang melakukan ritual-ritual peribadatan dan simbol-simbol yang ada. Pendidikan harus memiliki nilainilai akhlak atau karakter mulia untuk dapat meningkatkan kecerdasan spiritual dari peserta didiknya. Bukan hanya sekedar kognisi saja, akan tetapi juga mengedepankan hubungan dengan Allah dan Rasul-Nya. kemudian semua proses pendidikan ini juga bisa berpacu pada pendidikan karakter yang dicontohkan oleh Syekh al-Sya' rani dengan mengedepankan dan menekankan pada dimensi kesadaran Ilahi, tidak hanya pada pengembangan ilmu pengetahuan tetapi juga afeksi atau aspek kesadaran dan psikomotorik menuju terbentuknya akhlak karimah (Zubaidi, 2015).

Juga terdapat skripsi yang bersangkutan dengan judul Konsep Tasawuf K.H. Ahmad Rifai dan Relevansinya Terhadap Pendidikan Islam dalam Kitab Abyan al-Hawaij merupakan skirpsi yang disusun oleh seorang mahasiswa Jurusan Kependidikan Islam Fakultas Ilmu Tarbiyah dan Keguruan di Universitas Islam Negeri Sunan Kalijaga Yogyakarta bernama Fery Listiyanto pada tahun 2017. Dalam skripsinya ia menjelaskan beberapa hal tentang hubungan antara tasawuf dan akhlak karimah. Dijelaskan bahwa K.H. Ahmad Rifai pernah berkata bahwa merupakan tasawuf inilah yang mengajarkan akhlak (Listiyanto, 2017). Begitu juga dengan artikel milik Agus Susanti yang memiliki hubungan dengan tema artikel ini, dengan judul Penanaman Nilai-nilai Tasawuf dalam Pembinaan Akhlak. Di dalamnya dikatakan bahwa tasawuf merupakan upaya pelatihan jiwa dengan melakukan berbagai ritual atau kegiatan pembebasan diri dari dunia, dengan tujuan terpancarnya akhlak yang mulia dan memunculkan kedekatan dengan Allah SWT. Dikatakan juga bahwa dasar dari tasawuf 
sendiri adalah memupuk sifat ihsan dalam perilaku sehari-hari agar dapat merasakan kedekatan dengan sang Ilahi (Susanti, 2016).

Dari sekian penelitian yang kami temukan, tidak ada satupun yang mencoba untuk membahas tentang penggabungan pemikiran antara Syekh Abdul Wahhab al-Sya'rani dengan Syekh Muhammad Abdul Aziz alKhawli. Bahkan, penelitian yang mendalam tentang Syekh Muhammad Abdul Aziz al-Khawli tidak dapat ditemukan. Maka akan sangat menarik jika penelitian mengenai pemikiran kedua tokoh ini tentang akhlak yang mulia digabungkan dan dibahas lebih lanjut.

Kemudian artikel ini akan mencoba untuk mengupas konsep akhlak yang dikemukakan oleh dua tokoh agung dengan sudut pandang yang berbeda. Salah satu di antaranya adalah tokoh sufi Syekh Abdul Wahhab al-Sya'rani dengan karangannya al-Minan al-Kubra dan tokoh ahli hadits Syekh Muhammad Abdul Aziz al-Khawli dengan karya yang berjudul alAdab al-Nabawi. Dengan harapan bisa memberikan sumbangsih pemikiran tentang akhlak para sufi yang kerap dianggap bid'ah oleh sebagian ulama.

\section{Metode Penelitian}

Jenis penelitian yang akan digunakan dalam penelitian ini adalah penelitian kualitatif. Penelitian kualitatif adalah metode dalam suatu penelitian yang naturalistik, karena digunakan untuk meneliti objek dalam kondisi yang alami (natural). Objek alamiyah adalah objek yang berkembang dengan sendirinya, tanpa harus dimanipulasi oleh seorang peneliti dan juga dengan adanya peneliti yang hadir dalam objek tersebut tidaklah berpengaruh pada perkembangan objek tersebut (Sugiyono, 2018). Dalam penyusunannya, penelitian mengguanakan literature review atau kajian pustaka. Kajian pustaka adalah suatu penelusuran atau penelitian dengan membaca berbagai buku, jurnal dan terbitan-terbitan yang dapat dikaitkan dengan topik utama pembahasan penelitian (Marzali, 2016).

Teknik analisis yang digunakan merupakan teknis analisis komparatif. Teknik ini berguna untuk membandingkan pendapat dua tokoh atau lebih pada bagian-bagian tertentu saja (Mahmud, 2011). Dalam hal ini, buku utama yang akan digunakan adalah al-Minan al-Kubra karya Syekh Abdul Wahhab al-Sya'rani dan al-Adab al-Nabawi karya Syekh Muhammad Abdul Aziz al-Khawli.

\section{Hasil dan Pembahasan}

\section{Biografi Syekh Abd al-Wahhab al-Sya'rani}

Syekh Abdul Wahhab al-Sya'rani merupakan salah seorang ulama yang lahir di Mesir tepatnya di Qalqasyandah, kampung halaman kakeknya dari jalur ibu. Beliau lahir akhir bulan Ramadhan tepatnya di tanggal 27 di tahun $898 \mathrm{H}$. atau di tahun 1493 M. Beliau sudah memiliki hafalan al-Qur'an di usianya yang masih muda, dan juga hafal akan matan 
Abu Syuja' dan Ajurumiyyah. Beliau mempelajari dua matan tersebut dengan kakaknya yang juga seorang ulama. Bahkan di usianya yang baru memasuki 10 tahun dari hidupnya, beliau sudah mampu memiliki sikap zuhud, qona'ah dan tawakkal, jauh dari kemewahan dunia, dan hidup di kalangan kaum sufi (Hidayat, 2020).

Nama lengkap beliau adalah Abul Mawahib Abdul Wahhab ibn Ahmad ibn Ali ibn Ahmad ibn Muhammad ibn Dzauqa ibn Musa ibn Ahmad seorang sultan yang hidup di kota Tunis pada zaman syekh Abu Madyan, putra Sultan Said ibn Sultan Qasim ibn Sultan Yahya ibn Sultan Dzauqa. Dan nasab beliau berakhir di Muhammad ibn al-Hanafiah r.a. (AlSya'rani, 2011). Konon nenek moyangnya yang bernama Musa Abu Imran yang merupakan putra dari seorang Sultan di suatu wilayah di Afrika Utara ini, diutus oleh Syekh Abu Madyan Syu'aib al-Tilmisani (salah seorang tokoh ulama Syadzili) untuk berpartisipasi dalam kelompok ekspedisi dakwah yang diadakan di daerah terpencil di wilayah Mesir. Kemudian nenek moyangnya ini akhirnya meninggal di sebuah daerah bernama Hua di tahun $707 \mathrm{H}$. setelah dakwaknya berhasil dan masyarakat pedalaman mulai mengikuti jalan sufinya (Zubaidi, 2015). Syekh alSya'rani sudah menjadi yatim piatu dan hidup tanpa belaian ayah dan ibunya sejak usia dini. Oleh karenanya, beliau diasuh oleh kakaknya yaitu syekh Abdul Qodir yang merupakan seorang sufi. Berkat bimbingan dari kakaknya, beliau bisa menjadi seorang da'i yang handal dan terkenal di masyarakat sekitar pada usianya yang masih terbilang muda (Nasution, 2015).

Sebagai ulama yang produktif, beliau menuliskan beberapa karya yang tidak diketahui jumlah pastinya. Karyanya mencakup ilmu pengobatan, nahwu, fikih, tasawuf, tafsir dan lain sebagainya. Beberapa orang berpendapat bahwa jumlah karyanya berkisar 300 manuskrip. Tetapi menurut kajian seorang alhi bernama Ali Mubarok bahwa karya beliau yang terdeketsi ada sekitar 70 buah. Dan karya beliau tidaklah karya yang hanya sekedar berisi catatan kecil, akan tetapi ada beberapa karyanya yang berjilid-jilid. Bahkan ada yang berjumlah 15 jilid banyaknya. Di perpustakaan Mesir, karya al-Sya'rani ada sekitar 50 manuskrip yang beberapa di antaranya masih berupa manuskrip asli. Meskipun beliau memiliki berbagai karya di berbagai bidang, selama masa hidupnya bahkan setelah wafatnya beliau dikenal sebagai pimpinan kaum sufi dan ilmuan di bidang tasawuf (Huda M. , 2010).

Beliau memiliki banyak guru, di antaranya ialah Syekh Zakariya alAnshari, Imam Jalaluddin al-Suyuti, Syekh Nasiruddin al-Luqqani, Syekh Ali al-Khawwas al-Barlisi (Nasution, 2015). Sedangkan Syekh Ali alKhawwas merupakan guru besar sufi bagi Syekh Sya'rani, Syekh Sya'rani mengikuti majelisnya selama sekitar 10 tahun. Menurut Syekh Sya'rani, Syekh Ali al-Kawwas merupakan orang yang ummi. Tapi hakikatnya yang 
ummi bukanlah beliau, karena ilmu pengetahuannya bahkan lebih luas dibandingkan dengan manusia pada normalnya. Sebagai seorang sufi, Syekh Sya'rani mengikuti tarekat yang dibangun oleh Syekh Abul Hasan al-Syadzili. Beliau juga sempat mendirikan sebuah tarekat dengan nama tarekat al-Sya'rawiyyah akan tetapi tarekatnya tidaklah masuk dalam deretan tarekat yang masyhur (Al-Sya'rani, 2012).

\section{Biografi Syekh Muhammad Abdul Aziz al-Khawli}

Syekh Muhammad Abdul Aziz ibn Ali al-Syadzili al-Khawli merupakan salah seorang ulama ahli hadits yang berasal dari Mesir. Beliau lahir di tahun $1310 \mathrm{H}$. atau pada tahun $1892 \mathrm{M}$. Beliau wafat pada tahun 1349 H. atau tahun 1931 M. Beliau meninggal pada usia yang cukup muda, yaitu usia yang kurang dari 50 tahun, bahkan 40 tahun pun tidak sampai. Beliau memiliki beberapa karya. Di antaranya adalah al-Adab al-Nabawi, Miftah al-Sunnah dan Ishlah al-Wa'dz al-Dini (Al-Zirikli, 1986).

\section{Pemikiran Syekh Abdul Wahhab al-Sya'rani}

Syekh Sya'rani menegaskan bahwa ketika seseorang pernah melakukan suatu akhlak baik, walaupun hanya satu kali dalam hidupnya maka dia sudah menjadi pemilik dari akhlak tersebut. Sepeti contohnya untuk bersikap dermawan bukanlah kita harus selalu memberi kepada orang lain tanpa memperhitungkan lagi apa yang kita miliki. Sekali kita bersedekah, maka sebenarnya kita sudah menjadi ahli sedekah sudah menjadi akhlak yang kita miliki. Walaupun tidak mengulanginya lagi. Syekh al-Sya'rani mengatakan hal ini didasari karena tidak adanya titah pengulangan dalam hal ini (Al-Sya'rani, 2020).

Syekh al-Sya'rani merupakan salah satu ulama sufi yang unik, karena beliau menulis sendiri beberapa akhlak yang beliau miliki dalam kitab khusus yaitu al-Minan al-Kubra aw Lathaif al-Minan fi Wujub al-Tahadduts bini'mah Allah 'ala al-Ithlaq. Tidak terhitung berapa akhlak yang beliau miliki dan beliau sebutkan dalam kitanya tersebut, akan tetapi beliau menyebutkan beberapa alasan di dalam kitab tersebut tepatnya dalam muqaddimah (pendahuluan) mengapa beliau menuliskan tentang dirinya sendiri dalam suatu kitab. Al-Sya'rani mengemukakan alasannya adalah (Al-Sya'rani, 2020):

Pertama, karena tidak adanya yang mengikuti beliau jika hanya berupa tindakan belaka. Dengan itu beliau kemudian diminta oleh salah seorang sahabat agar menuangkan akhlak agungnya dalam sebuah tulisan. Lalu beliau memutuskan untuk melakukan shalat istihkarah dan menemukan jawaban untuk menuliskannya supaya lebih mudah untuk diikuti, karena beberapa orang sulit untuk meniru jika hanya melihat saja tanpa ada penjelasan lebih lanjut mengenai hal tersebut.

Kedua, karena sesungguhnya syukur seorang hamba yang setiap hari diucapkannya akan berakhir bersamaan dengan datangnya ajal, akan tetapi 
jika akan berbeda jika bentuk syukurnya dituliskan dalam suatu karangan, bahkan setelah kematiannya pun, rasa syukurnya akan selalu ada selama karangan tersebut masih ada, seakan-akan pengarang terus hidup dalam keadaan bersyukur. Maka beliau berniat untuk mendawamkan syukurnya kepada Allah Swt yang telah menganugerahi beliau dengan segala hal yang beliau miliki termasuk akhlak tersebut dengan menuliskannya. Dengan begitu syukur beliau tidak terbatas pada usia yang telah usai.

Ketiga, memberitahukan kepada seluruh penduduk pada zamannya tentang derajat beliau dalam ilmu dan amal, agar beliau diikuti dalam istiqamahnya terhadap ajaran-ajaran syariat. Karena sesungguhnya jalan yang ditempuh oleh suatu kaum itu haruslah sesuai bersumber dari kitab dan sunnah, maka penempuhnya itu membutuhkan timbangan syar'i dalam setiap gerakan maupun diamnya.

Keempat, mempersempit kemungkinan salah kepada orang-orang yang mencoba untuk menyebutkan manaqib atau riwayat kehidupan beliau di kemudian hari. Kesalahan mungkin saja terjadi baik pengurangan atau penambahan karena penulis tidak merasakan apa yang dituliskan. Mereka hanya bisa menyangka tanpa keyakinan bahwa pemilik riwayat melakukan ini dan itu. Lalu bagaimana ia bisa meyakinkan orang lain dengan itu? Maka satu-satunya orang yang bisa memberikan keyakinan adalah pelakunya sendiri, tentunya itu bisa jika dia seorang yang jujur.

Kelima, mengikuti apa yang telah dilakukan oleh para salafus shalih, karena beberapa ulama dari orang-orang terdahulu telah mencoba menyebutkan manaqibnya sendiri dalam sebuah karya, sebagai bentuk tahadduts binni'mah. Di antara ulama tersebut adalah Syekh al-Imam alFaqih Abd al-Ghafir al-Farisi, al-Faqih Yaqut al-Hamawi, Syekh al-Hafidz Ibnu Hajar, Syekh Jalal al-Din al-Suyuti dan lain sebagainya.

Dari sekian akhlak yang beliau sebutkan dalam tulisannya, beliau tidak pernah luput untuk menyebutkan kata:

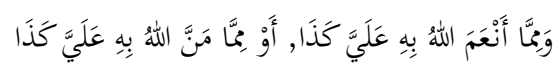

Yang artinya kurang lebih adalah "sebagian dari nikmat yang Allah berikan kepadaku/sebagian dari anugerah yang Allah karuniakan kepadaku adalah ini, ini dan ini."

Hal ini beliau lakukan untuk menjadi sebuah isyarat atau petunjuk kepada para pembaca kitabnya bahwa yang beliau lakukan berupa penyebutan cerita-cerita tentang dirinya sendiri bukanlah untuk menyombongkan diri dan menunjukan tentang kelebihannya kepada orang lain yang membaca tentang dirinya. Beliau melakukan semua itu tidak lain dan tidak bukan hanyalah suatu cara untuk mengungkapkan rasa 
syukurnya kepada Allah Swt yang selalu memberinya nikmat. Kemudian beliau mengatakan jika dalam penyebutan akhlaknya kemudian berlanjut dengan pemujian dirinya, itu bukanlah tujuannya, akan tetapi itu hanyalah sampingan untuk melengkapi ceritanya. Dan pelengkap atau sampingan itu adalah hal yang sangat berbeda dengan tujuan utama. Sebagaimana orang yang sedang dalam keadaan junub kemudian membaca beberapa ayat al-Qur'an untuk tujuan berdzikir, tidak akan menjadi masalah karena berdzikir bukanlah hal yang dilarang selama masa junub yang dilarang adalah membaca al-Qur'an, dan membaca al-Qur'an ketika itu bukanlah tujuan utamanya (Al-Sya'rani, 2020).

Penulisan tentang manqibnya sendiri juga didasari dari perkataan dari guru sufinya yang agung yaitu Syekh Ali al-Khawwas. Syekh Ali pernah berkata "sebutkanlah kesempurnaan-kesempurnaanmu sebisa yang kamu mampu, karena dengan hal tersebut ekspresi syukurmu kepada Allah akan menjadi banyak. Dan hati-hatilah, jangan terlalu banyak menyebutkan kekuranganmu, karena dengan hal tersebut rasa syukurmu akan menjadi sedikit" (Al-Sya'rani, 2020). Kebanyakan orang yang sering menyebutkan kekurangannya dalam hal ibadah atau yang lainnya, dia akan cenderung mengeluh akan apa yang telah dikaruniakan oleh Allah kepadanya. Sedangkan orang yang selalu menyebutkan kelebihannya dia bisa menyebutkannya dengan menyandarkan kelebihannya kepada Allah, sehingga dia menjadi orang yang bersyukur kepada Allah Swt.

\section{Pemikiran Syekh Muhammad Abdul Aziz al-Khawli}

Akhlak yang terdefinisikan oleh syekh Muhammad Abdul Aziz alKhawli adalah semua sifat yang berakar dari dalam diri seseorang yang mendorong seseorang melakukan sesuatu dengan luwes tanpa adanya beban untuk melakukannya. Seperti dicontohkannya adalah sifat dermawan, ketika seseorang mampu memberikan sebagian dari hal yang dimilikinya kepada orang lain yang tidak bekerja kepadanya. Kemudian beberapa orang mengartikan akhlak adalah keinginan yang dibiasakan. Dan karena akhlak hanyalah hal yang ada dalam diri seseorang, maka akhlak juga memiliki potensi baik dan buruk (Al-Khawli, 2017).

Nabi Muhammad Saw sebagai utusan Allah yang terakhir merupakan manusia dengan Akhlak yang sempurna, bahkan dididik langsung oleh Allah Sang Maha segalanya dengan ayat-ayat-Nya yang diturunkan kepada Nabi Muhammad Saw. Maka dari diri Nabi sering sekali muncul kalam-kalam untuk mendidik diri dan memperbaiki akhlak. Dari kalam tersebut para ulama mencoba menjelaskannya dengan berbagai penjelasan dan syarah. Akan tetapi kemudian dimasukkan kedalam penjelasaan tersebut ungkapan yang berulang-ulang dan riwayat yang beraneka ragam. Kemudian mereka juga menuliskannya berdasarkan masa sendiri sehingga membuat pembacanya akan merasa bosan, karena seakan-akan 
menjauhkannya dari masa pembaca itu. Belum lagi jika penulisnya tidak memiliki ilmu yang mumpuni mengenai riwayat. Maka dari itu syekh alKhawli mencoba untuk mencantumkan ratusan hadits dengan penjelasannya (Al-Khawli, 2017).

Syekh al-Khawli merupakan ulama yang sangat berpegang teguh pada kitab dan sunnah. Bahkan beliau sempat mengatakan bahwa orang yang tidak memiliki ilmu tentang kitab dan sunnah tidaklah pantas untuk menjelaskan satu hal pun tentang agama dan syariat Nabi Muhammad, dan dia tidak akan memiliki cahaya yang akan meneranginya dari gelapnya keragu-raguan dan kebatilan. Maka semua kabaikan yang ada haruslah dalam koridor yang ada dalam kitab dan sunnah, dan menyelami samudera keduanya yang sangat luas. Karena tidak ada hal yang memberikan petujuk dan menarik kebahagiaan jiwa serta mensucikannya melebihi dari pada memahami kitab dan sunnah dan tadabbur (Al-Khawli, 1986).

Karena hal tersebut Syekh al-Khawli menjelaskan akhlak berdasarkan hadits-hadits yang shahih. Berbeda dengan Syekh al-Sya'rani yang menjelaskan kajian tentang akhlak dengan berpacu pada guru-guru beliau dan perilakunya sehari-hari dan diperkuat dengan adanya beberapa hadits tentang akhlak tersebut. Syekh al-Khawli menuliskan hadits, lalu menjelaskannya dengan pola makna secara bahasa untuk beberapa kata khusus, kemudian dijelaskan secara rinci oleh beliau di paragraf selanjutnya. Seperti contohnya beliau mejelaskan hadits yang diriwayatkan oleh sahabat Abdullah ibn 'Umar tentang rukun Islam yang berbunyi:

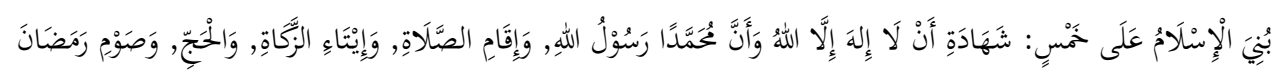

"Islam dibangun atas lima dasar: bersaksi bahwa tiada Tuhan selain Allah dan Muhammad adalah utusan Allah, mendirikan shalat, memberikan zakat, berhaji dan berpuasa pada bulan Ramadhan."

Sebelum beliau menjelaskan isi tentang haditsnya, beliau menjelaskan terlebih dahulu apa itu Islam. Baru setelah penjelasan tentang Islam secara bahasa selesai, beliau menjelaskan maksudnya secara terperinci di paragraf selanjutnya (Al-Khawli, 2017).

Akhlak yang baik tidaklah hanya berbuat baik kepada manusia, akan tetapi juga kepada makhluk yang lain seperti hewan. Kebanyakan dari manusia tidaklah mempedulikan akan nasib makhluk lain, sehingga dengan mudahnya membunuh hewan dan bahkan menyiksanya. Hal itu sangat tidak sesuai dengan apa yang dipraktikkan oleh Rasulullah Saw, dimana beliau sangat berbelas kasihan kepada seluruh makhluk Allah bahkan terhadap hewan (Al-Khawli, 2017). 
Beberapa ulama menafikan adanya tasawuf karena ada yang beranggapan bahwa tasawuf tidak berdasarkan al-Qur'an dan hadits. Padahal tidaklah demikian adanya. Perlu dipertegas bahwa siapapun yang menganggap bahwa sufi tidak sesuai dengan syariat dan berada di luar batas syari' at maka sebenarnya dia hanyalah berdusta. Bahkan syekh Abd al-Wahhab al-Sya'rani menyatakan bahwa orang yang mengatakan bahwa tasawuf tidak sesuai dengan al-Kitab dan al-Sunnah adalah orang yang bodoh. Karena sesungguhnya sufi adalah orang yang mengamalkan ilmu yang dia punya secara ikhlas, tanpa ada tujuan lain (Al-Sya'rani, 2012). Hal ini sesuai dengan ucapan buya Nursamad Kamba dalam prakata buku "Kids Zaman Now Menemukan Kembali Islam" di mana bertasawuf adalah ber-Islam (Kamba, 2018). Karena memang itulah yang dinamakan Islam, ketika seseorang beramal dengan ikhlas, dan pasrah kepada yang Maha Kuasa. Bahkan dikatakan bahwa sufi merupakan orang yang selalu mengamalkan apa yang ada dalam al-Qur'an dan sunnah sehingga sufi dan Qur'an hadits diibaratkan sebagai benda dan bayangannya. Ketika benda bergerak kemanapun itu, bayangannya akan selalu mengikutinya. Dan ketika tidak ada bayangan tersebut artinya bendanya juga sudah pergi dari tepat itu (Al-Sya'rani, 2017).

Tasawuf bukan tentang orang yang bisa memberikan beberapa keramat atau kesaktian yang bisa digolongkan sebagai hal yang tidak lumrah dan tidak masuk dalam akal. Bahkan ada beberpa orang yang ketika tersebutkan nama tasawuf, hal yang pertama terbesit dalam benaknya adalah dukun. Banyak orang yang terjebak dalam hal tersebut, mereka menyebut bahwa indikasi seorang sufi merupakan orang yang berpakaian lusuh, mampu terbang tanpa adanya sayap dan tidak menunggangi kendaraan seperti pesawat, berjalan di atas air dan keramatkeramat lainnya. Padahal sesungguhnya itu bukanlah syarat seseorang bisa disebut sebagai sufi, itu hanyalah bukti yang diberikan oleh Allah kepada beberapa hamba-Nya bahwa Allah mampu menciptakan apapun bahkan hal yang tidak sewajarnya tidak terjadi di hadapan manusia. Bahkan jika seseorang bangga dan merasa bangga akan dirinya karena bisa melakukan berbagai hal tersebut maka dia hanyalah orang yang tertipu dan terlena dan sama sekali orang tersebut tidak bisa disebut sebagai sufi. Memiliki kemampuan seperti itu bukanlah esensi dari kehidupan seorang sufi, karena hakikatnya tasawuf adalah kemampuan diri untuk mengendalikan hawa nafsu sehingga bisa bermusyahadah dengan yang Maha Esa (Huda S. , 2008).

Jika konsep tentang akhlak mulia dibandingkan antara keduanya, maka dapat dijelaskan secara ringkas komparasi antara Syekh Abdul Wahhab al-Sya'rani dengan Syekh Muhammad Abdul Aziz al-Khawli dalam tabel berikut: 
Tabel.1 Perbandingan Pendapat al-Sya'rani dan al-Khawli

\begin{tabular}{|c|c|c|c|}
\hline \multirow{2}{*}{ No. } & \multirow{2}{*}{ Aspek } & \multicolumn{2}{|c|}{ Konsep Akhlak } \\
\hline & & al-Sya'rani & al-Khawli \\
\hline 1 & Dalil & $\begin{array}{l}\text { Al-Qur'an dan Hadits } \\
\text { serta beberapa perilaku } \\
\text { guru dan para salafus } \\
\text { shalih }\end{array}$ & Al-Qur'an dan Hadits \\
\hline 2 & Penjelasan & $\begin{array}{l}\text { Selalu menyertakan } \\
\text { penjelasan gurunya } \\
\text { tentang pendapatnya, } \\
\text { diperkuat dengan perilaku } \\
\text { para salafus shalih }\end{array}$ & $\begin{array}{l}\text { Lebih menjelaskan akhlak } \\
\text { sebagaimana beliau pahami } \\
\text { dari beberapa teks hadits, } \\
\text { tanpa pernah menyebutkan } \\
\text { guru-gurunya }\end{array}$ \\
\hline 3 & Aplikasi & $\begin{array}{l}\text { Memperlihatkan } \\
\text { akhlaknya sendiri agar } \\
\text { dapat ditiru oleh orang } \\
\text { lain dan muridnya, } \\
\text { bahkan menuliskannya } \\
\text { secara terperinci dalam } \\
\text { sebuah manuskrip }\end{array}$ & $\begin{array}{l}\text { Tidak pernah menyebutkan } \\
\text { bahwa dirinya pernah } \\
\text { melakukan suatu akhlak, } \\
\text { walaupun pastinya beliau } \\
\text { pernah melakukannya, } \\
\text { hanya menjelaskan hal } \\
\text { tersebut dalam syarah } \\
\text { suatu hadits atau } \\
\text { penjelasan terkait ayat al- } \\
\text { Qur'an }\end{array}$ \\
\hline
\end{tabular}

Baik Syekh Sya'rani yang berbasis sufi dan Syekh Khawli yang merupakan ahli hadits, keduanya memberikan pendapat tentang akhlak dengan langsung menyandarkannya kepada hadits Nabi Muhammad Saw, keudanya memiliki inti yang sama yaitu menjalankan perintah Allah dan menjauhi larangan-Nya. Seperti contoh dalam hadits ke 39 yang dituliskan oleh Syekh Khawli, beliau menjelaskan tentang bagaimana kita menghargai kesehatan orang lain dan sebagai manusia kita haruslah memiliki rasa peduli dengan memberikan makanan kepada orang yang membutuhkannya. Dengan memberikan makanan walaupun sedikit, maka kita telah melepaskan sakitnya kelaparan dari orang yang kita beri. Selain itu, juga kita telah berkontribusi dalam mencoba memberikan kesehatan, karena banyak orang yang sakit karena tidak makan berhari-hari. Tentunya makanan yang diberikan haruslah makanan yang halal dan baik, setidaknya itu adalah makanan yang layak untuk dimakan (Al-Khawli, 2017).

Demikian pula dalam pandangan Syekh Sya'rani sebagai seorang sufi. Meskipun kontesknya berbeda, tetapi intinya adalah sama. Beliau mengatakan dalam kitabnya di BAB yang ke-5 bahwasanya beliau tidak akan menerima suatu hadiah atau shadaqah yang diberikan kepadanya kecuali beliau sudah diyakinkan bahwa orang yang memberinya tidak lagi meninggalkan orang yang kelaparan atau lebih membutuhkan dari Syekh Sya'rani di kota atau negri pemberi tersebut (Al-Sya'rani, 2020). Ini adalah bentuk kepedulian beliau kepada orang-orang miskin dan orang-orang 
yang lebih membutuhkan. Tentunya hal ini bukan berarti beliau menolak shadaqah atau hadiah, akan tetapi beliau akan lebih senang jika shadaqah atau hadiah tersebut dialihkan kepada orang yang lebih membutuhkan.

Selain urusan sosial, keduanya juga membahas bagaimana adab seorang hamba dalam menyembah Tuhannya. Konsep akhlak tetap saja akan berpacu pada dua hal ini, bagaimana cara kita bersikap dengan Sang Pencipta dan bagaimana juga bersikap dengan ciptaan-Nya. Hal seperti ini juga sudah pernah dijelaskan dalam kitab Nashaih al-'Ibad karya Imam Nawawi yang disebutkan bahwa Nabi Muhammad pernah bersabda (Nawawi, 2012):

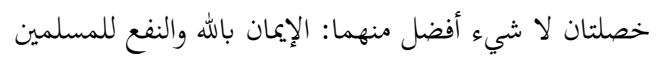

"Dua perkara yang paling utama tiada tanding adalah beriman kepada Allah Swt dan bermanfaat bagi orang muslim."

Begitu juga sebaliknya, jika beribadah kepada Sang Pencipta dengan cara yang baik dan menerapkan adab-adabnya serta bermanfaat bagi ciptaan-Nya merupakan yang paling utama, maka tidak menyembah-Nya dan membahayakan ciptaan-Nya merupakan hal yang paling buruk.

Melakukan perbuatan yang baik untuk mencerminkan akhlak yang baik juga harus dengan niat yang baik. Karena terkadang perbuatan yang baik akan menjadi kurang baik karena niatnya yang salah. Sebagai contoh yang dimisalkan oleh Syekh Khawli adalah ada dua orang yang bershadaqah. Salah satu dari mereka bershadaqah dikarenakan ingin memiliki pangkat dalam sebuah pemerintahan, sekolah atau tempat lainnya, atau agar orang lain menghormatinya. Sedangkan satu yang lainnya memberikan hartanya kepada orang lain karena ingin meringankan beban orang lain, melenyapkan kemadlaratan darinya atau hanya untuk menjalankan perintah Allah semata. Keduanya sama-sama melakukan hal yang sama yaitu shadaqah akan tetapi derajatnya sangat berbeda sekali dan sangat jelas. Orang pertama memiliki derajat yang lebih rendah karena dia bershadaqah karena alasan keduniawiyan. Sedangkan orang kedua memberikan sebagian hartanya karena memiliki mahabbah kepada sesama manusia, menginginkan kebaikan sesama manusia bahkan berharap akan ridla Allah Swt, tentu derajatnya akan lebih mulia dan lebih tinggi dibanding dengan orang yang pertama (Al-Khawli, 2017).

Niat merupakan inti dari sebuah ibadah. Jika niatnya baik maka bahkan amalan yang bersifat duniawi akan berubah menjadi amalan akhirat dengan niat yang benar. Begitu juga sebaliknya jika seseorang melakukan perbuatan akhirat akan tetapi dalam niatnya terdapat hal yang tidak benar maka amalannya akan berubah menjadi amalan duniawi. Seseorang haji 
dengan niat agar dipuji oleh manusia, tentu hajinya akan menjadi amal dunia. Akan tetapi ketika seseorang makan yang merupakan amalan dunia, akan tetapi dengan niat untuk memberikan kekuatan supaya dirinya sanggup beribadah dengan maksimal maka amalannya tercatat sebagai amalan akherat. Selain itu seorang mukmin juga harus pandai menata niat, agar perbuatannya tidak tersia-siakan. Seperti contohnya ketika berangkat ke masjid, dia berniat untuk melaksanakan ibadah shalat berjamaah, niatkanlah pula untuk menyambung tali silaturahmi dengan sesama muslim. Maka dengan itu perbuatannya akan bernilai ganda. Apalagi jika diniatkan untuk melakukan kebaikan lainnya seperti menuntut ilmu dan lainnya, maka perbuatannya akan merangkap menjadi berbagai kebaikan (Al-Sya'rani, 2017).

\section{Kesimpulan}

Akhlak merupakan pondasi berjalannya hidup seseorang, ia sangatlah penting untuk selalu diperbaiki. Sebaik apapun perilaku seseorang pastilah memiliki kekurangan karena tidak ada orang yang sempurna di dunia ini. Hanya Nabi Muhammad yang menjadi manusia paling sempurna baik fisik maupun akhlaknya. Maka dalam hal akhlak beliaulah yang menjadi panutan dan cerminan utama ummat manusia. Maka mempelajari sejarah Nabi dan hadits-haditsnya merupakan hal yang sangat penting untuk menunjang akhlak yang mulia. Karena kekurangan manusia, tidak akan ada yang mampu meniru akhlak beliau sama persis dengan yang beliau lakukan, bahkan para sahabat yang hidup bersama beliau. Sebagai manusia yang hidup sekitar 14 abad setelah Nabi wafat yang bisa dilakukan hanyalah meniru orang-orang shalih yang masih hidup, atau membaca karya-karya ulama terdahulu tentang akhlak Nabi.

Beberapa ulama membahas sifat dan akhlak Nabi dengan cara yang berbeda-beda sesuai dengan ilmu yang beliau miliki. Tidak jarang cara ulama sufi dalam mengimplementasikan akhlak Nabi dianggap tidak tepat. Setalah mengupas beberapa akhlak yang tercantum dalam kitab al-Minan al-Kubra karya seorang sufi bernama Imam Sya'rani, ternyata sufi bukanlah orang yang selalu berperilaku aneh seperti yang diyakini beberapa orang. Bahkan akhlak yang dipraktikkan tidaklah berlawanan dengan haditshadits Nabi yang dikutip dalam kitab al-Adab al-Nabawi milik Syekh alKhawli. Dari kedua ulama Mesir tersebut, keduanya memiliki prinsip yang sama yaitu berakhlak sebagaimana yang telah termaktub dalam al-Qur'an dan hadits. Dan inti dari semua akhlak yang ada adalah bagaimana seorang hamba memiliki hubungan yang erat dengan Tuhannya dan bisa bersosialisasi dengan rasa kepeduliannya. Bersosialisasi dengan seluruh makhluk Allah Swt, tidak hanya manusia tetapi juga dengan hewan, tumbuhan dan makhluk-makhluk lainnya. Hal yang membedakan keduanya ialah Syekh al-Sya'rani selalu mengaitkan akhlak yang beliau 
ceritakan atau jelaskan dengan perilaku guru beliau, atau bahkan para salafus shalih. Sedangkan Syekh al-Khawli tidak terlihat satupun pendapat beliau yan beliau kaitkan dengan gurunya. Bahkan untuk mengetahui siapa guru yang beliau anutpun sangatlah susah.

Manfaat yang bisa dipetik dari kedua ulama ini adalah sejauh apapun langkah yang coba kita tempuh untuk mendekatkan diri kepada Allah Swt, jangan sampai lupa kepada tuntunan utama peninggalan Rasulullah yaitu al-Qur'an dan hadits. Sifat tolerensi juga harus selalu dijunjung tinggi, karena dengan sifat inilah manusia bisa hidup rukun dan damai tanpa memperbesar perdebatan. Semua ilmu memiliki dasar dan dasar utama semua ilmu adalah al-Qur'an dan hadits. Penulis mengakui kurangnya referensi yang digunakan dalam menyusun artikel ini. Bahkan biografi dari Syekh al-Khawli tidak dapat penulis temukan sebanyak biografi Syekh alSya'rani. Sulitnya ditemukan referensi yang membahas tentang beliau adalah hambatan paling besar yang dihadapi, atau terbatasnya bahan bacaan yang dimiliki penulis juga merupakan faktor yang mempengaruhinya. Sekiranya penelitian ini akan dilanjutkan maka akan lebih sempurna jika dibahas secara mendetail metode yang digunakan oleh masing-masing ulama ini. Apakah yang mendasari mereka berfikir seperti itu. Dengan begitu pemikiran keduanya tentang segala hal akan dapat diterangkan dengan mudah dan jelas.

\section{Daftar Pustaka}

Abdillah, R. (2012). Kumpulan Tanya Jawab Bid'ah dalam Ibadah. Bekasi: Darul Falah.

al-Ghazali. (2020). Ihya 'Ulum al-Din. Surabaya: Pustaka Assalam.

al-Khawli, M. A. (1986). Tarikh Funun al-Hadits al-Nabawi. Beirut: Dar Ibn Katsir.

al-Khawli, M. A. (2017). Al-Adab al-Nabawi. Beirut: Dar Al-Kotob AlIlmiyah.

al-Sya'rani, A. W. (2011). Lawaqih al-Anwar al-Qudsiyyah fi Ma'rifah Qawa'id al-Shufiyyah. Dalam Wasmukan, Cahaya Suci pada Pintu-pintu Surga: Adab Bertasawuf dalam Bingkai Syar'i. Surabaya: Risalah Gusti.

al-Sya'rani, A. W. (2012). Tanbih al-Mughtarrin. Jakarta: Dar al-Kutub alIslamiyah.

al-Sya'rani, A. W. (2017). Tanbih al-Mughtarrin. In E. Wikarta, Jalan-jalan Surga: Akhlak dan Ibadah Pembuka Pintu Surga (p. 194). Bandung: PT Mizan Pustaka.

Al-Sya'rani, A. W. (2020). Al-Minan al-Kubra aw Lathaif al-Minan fi Wujub alTahadduts bi Ni'mah Allah 'ala al-Ithlaq. Beirut: Dal al-Kutub alislamiyah.

Al-Zirikli, K. (1986). Al-A'lam. Beirut: Dar al-Ilm Lilmalayin.

Bahri, K. (2015). Metode Kompromistik Imam Sya'rani Dalam Ta'arudh Al- 
Adillah Dan Implikasinya Terhadap Ijtihad Hukum Islam. Journal Analytica Islamica, 4(1), 130-154.

Hamka. (2017). Akhlaqul Karimah. Depok: Gema Insani.

Hasan, I. (2014). Tasawuf: Jalan Rumpil Menuju Tuhan. An-Nuha: Jurnal Kajian Islam, Pendidikan, Budaya Dan Sosial, 1(1), 45-63.

Hidayat, A. T., \& Alfurqan, A. (2020). Pluralistic Fiqh Based on Perspective of Imam Al-Sya'rani in The Book of Al-Mizan Al-Kubra. JURNAL ILMIAH MIZANI: Wacana Hukum, Ekonomi, dan Keagamaan, 7(2), 83-94.

Huda, M. (2010). Epistemologi Tasawuf dalam Pemikiran Fiqh Al-Sya 'Rânî. Ulumuna, 14(2), 249-270.

Huda, S. (2008). Tasawuf Kultural: Fenomena Shalawat Wahidiyah. Yogyakarta: LKIS Pelangi Aksara.

Kamba, D. M. (2018). Kids Zaman Now Menemukan Kembali Islam. Bandung: Pustakan IIman.

Listiyanto, F. (2017). Konsep Tasawuf K.H. Ahmad Rifai dan Relevansinya Terhadap Pendidikan Islam dalam Kitab Abyan Al-Hawaij. Yogyakarta.

Lubis, A. S. (2012). Konsep Akhlak dalam Pemikiran al-Ghazali. HIKMAH: Jurnal Ilmu Dakwah dan Komunikasi Islam, 6(1), 58-67.

Marzali, A. (2017). Menulis Kajian Literatur. ETNOSIA: Jurnal Etnografi Indonesia, 1(2), 27 - 36.

Nawawi, M. (2012). Nashaih Al-'Ibad. Beirut: Dar Al-Kotob Al-Ilmiyah.

Rahman, F. (2017). Islam: Sejarah Pemikiran dan Peradaban. Bandung: PT Mizan Pustaka.

Sugiyono. (2018). Metode Penelitian Kuantitatfi, Kualitatfi, dan Kombinasi (Mixed Methods). Bandung: Alfabeta.

Susanti, A. (2016). Penanaman Nilai-Nilai Tasawuf dalam Pembinaan Akhlak. Al-Tadzkiyyah: Jurnal Pendidikan Islam, 7(2), 277-298.

Zubaidi. (2015). Abdul Wahhab Asy-Sya'rani: Sufisme dan Perkembangan Pendidikan Karakter. Yogyakarta: Kaukaba Dipantara. 